\title{
Color correction of a publication error in the Tan Hamlet and the second occurrence of a Potentially Inheritable Character the Butter Hamlet (Perciformes: Serranidae)
}

\author{
E.H. Williams, Jr., ${ }^{1}$ L. Bunkley-Williams, ${ }^{2}$ C.S. Rogers, ${ }^{3}$ \& R.M. Fenner ${ }^{4}$ \\ 1. Department of Marine Sciences, University of Puerto Rico, P.O. Box 9013, Mayagüez, Puerto Rico 00667; ewil- \\ liams@uprm.edu \\ 2. Caribbean Aquatic Animal Health Project, Department of Biology, University of Puerto Rico, P.O. Box 9012, \\ Mayagüez, Puerto Rico 00861; lwilliams@uprm.edu \\ 3. Virgin Islands National Park, U.S. Geological Survey, Biological Resources Division, Florida Caribbean Science \\ Center, P.O. Box 710, St. John, US Virgin Islands 00830; caroline_rogers@usgs.gov \\ 4. Web Web Media, 8586 Menkar Road, San Diego, California, USA 92126; BobFenner@WetWebMedia.com \\ Corresponding author; ewilliams@uprm.edu
}

\section{Received 15-VIII-2007. C Corrected 01-XI-2007. Accepted 13-II-2008.}

\begin{abstract}
Color photographs of Tan Hamlets, Hypoplectrus sp., from St. John and St. Thomas, U.S. Virgin Islands are presented to correct a printing error in a hamlet paper in the last Proceedings. These figures were accidentally printed in black-and-white rendering them diagnostically useless. The Double-Spot Anomaly in the Butter Hamlet was suggested as a Potentially Inheritable Character (PIC) that could lead to speciation. Identifying and following PICs in the field were suggested as a means to study speciation and evolution. Finding a second individual with the Double-Spot Anomaly means it is much more likely to be an inheritable character leading to speciation from the Butter Hamlet. This could represent the first successful recognition of a PIC leading to a new species. Rev. Biol. Trop. 56 (Suppl. 1): 289-292. Epub 2008 May 30.
\end{abstract}

Key words: color characteristics, field speciation study, evolution, new study discipline, Hypoplectrus.

Williams et al. (2007) reported two records of Tan Hamlet, Hypoplectrus sp. (Perciformes: Serranidae), from St. John and St. Thomas, U.S. Virgin Islands. Species of hamlets have only been distinguished by their color patterns; therefore, the manuscript was submitted and approved with color illustrations. Unfortunately, it was published with only diagnosticallyuseless black-and-white photographs. These illustrations (Figs. 1-2) are repeated below in color to properly confirm the species.

Williams and Bunkley-Williams (2007) reported a Double-Spot Anomaly in the Butter Hamlet, Hypoplectrus unicolor (Walbaum), providing a field drawing of this anomaly and a drawing of the normal caudal peduncle spot in this species. After attending the oral presentation of that paper (Williams and Bunkley-Williams, 2005), Caroline Rogers photographed another Butter Hamlet specimen (Fig. 3) with the Double-Spot Anomaly May 2007 at Maho Bay, St. John, U.S. Virgin Islands $\left(18^{\circ} 21.3^{\prime} \mathrm{N}, 64^{\circ} 44.8^{\prime} \mathrm{W}\right)$. Williams and Bunkley-Williams (2007) original observation was made at Whistling Key $\left(18^{\circ} 22.1^{\prime} \mathrm{N}\right.$, $\left.64^{\circ} 45.3^{\prime} \mathrm{W}\right) 2.6 \mathrm{~km}$ north of the new one. Since hamlets only have small territories on the reef, do not move across relatively deeper-water areas as adults, and do not migrate, the second observation represents a second individual with the Double-Spot Anomaly. Thus far this anomaly is only known from a very small geographic area, but could possibly be established in the population. This photograph also 


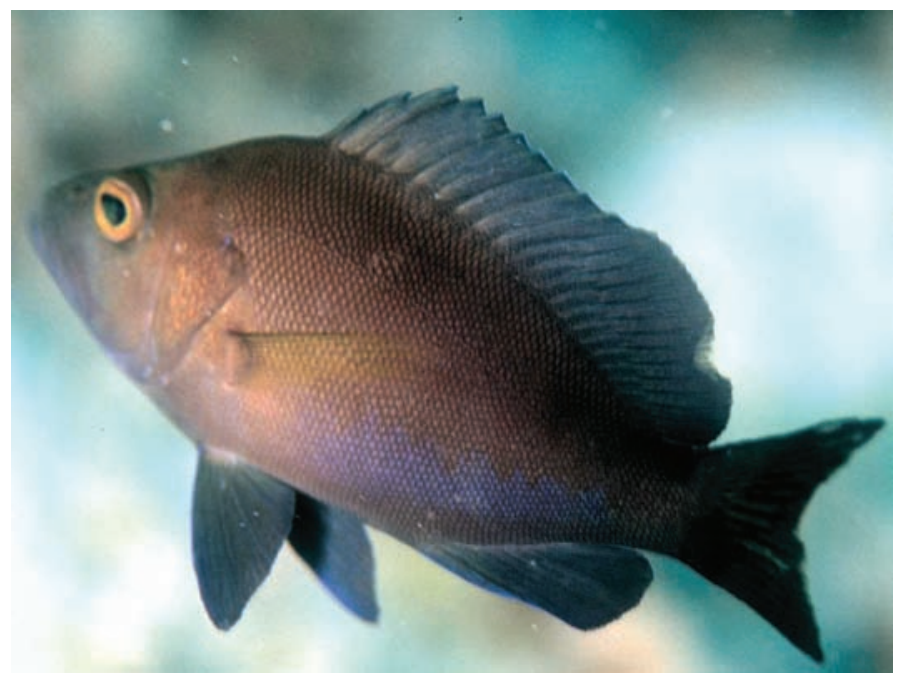

Fig. 1. Tan Hamlet, Hypoplectrus sp., photographed in 2001 by Robert Fenner at Water Bay, St. Thomas, U.S. Virgin Islands $\left(18^{\circ} 20.6^{\prime} \mathrm{N}, 64^{\circ} 51.6^{\prime} \mathrm{W}\right)$.

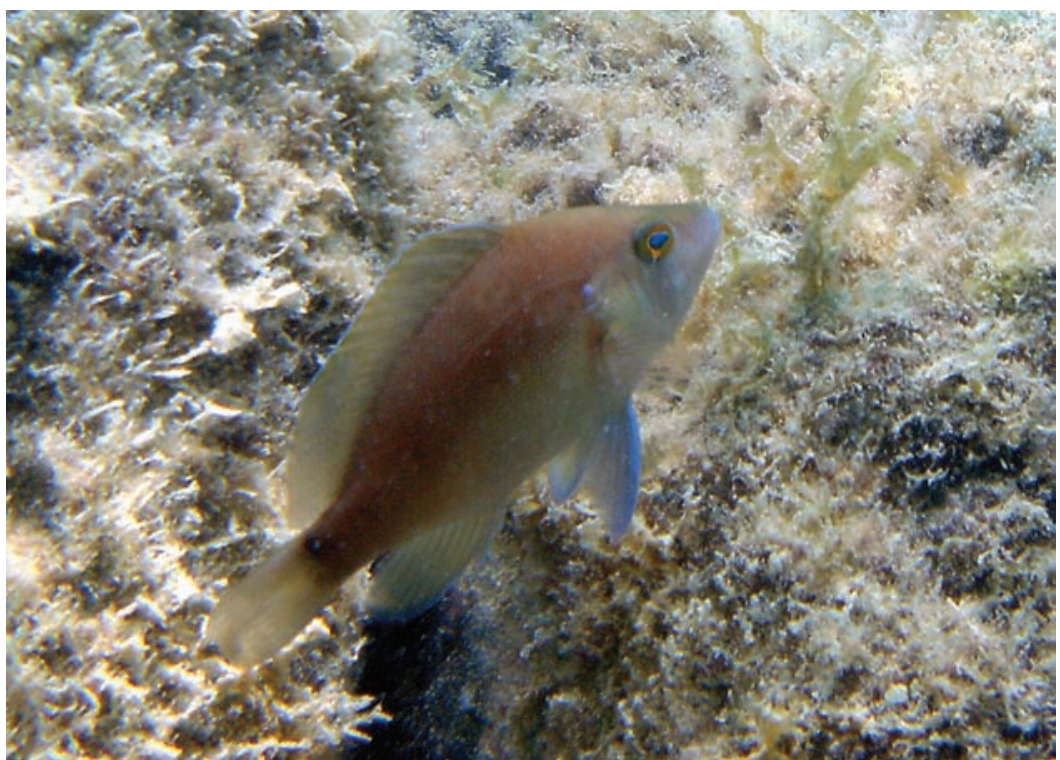

Fig. 2. Tan Hamlet, Hypoplectrus sp., photographed in June 2005 by Caroline Rogers at Lameshur Bay, St. John, U.S. Virgin Islands $\left(18^{\circ} 19.2^{\prime} \mathrm{N}, 64^{\circ} 43.6^{\prime} \mathrm{W}\right)$.

reconfirms the field drawing and observation of Williams and Bunkley-Williams (2007) since a photograph is more conclusive evidence than a field drawing.
Williams and Bunkley-Williams (2007) suggested that this anomaly could represent a Potentially Inheritable Character (PIC) possibly leading to speciation if it becomes established. 


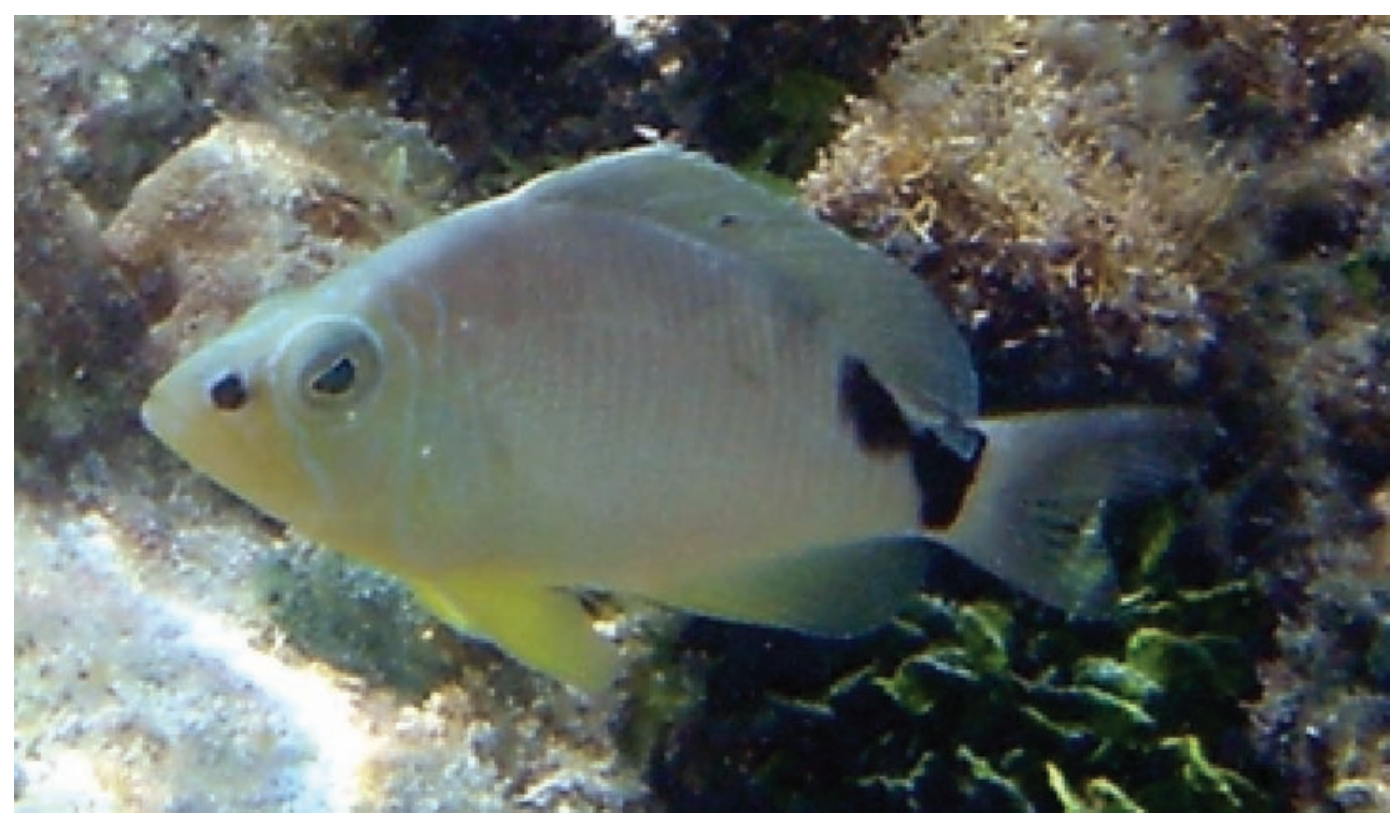

Fig. 3. Butter Hamlet, Hypoplectrus unicolor, with the Double-Spot Anomaly photographed in May 2007 by Caroline Rogers at Maho Bay, St. John, U.S. Virgin Islands (18²1.3’N, 6444.8’ W).

The new observation represents the first time a PIC was described and later found again in a wild population. More observations are needed to determine if this anomaly represents an inherited character and if speciation may be in progress.

Williams and Bunkley-Williams (2007) proposed a new discipline or method to study evolution and speciation. They suggested that some anomalies in individuals could be recognized as characters that might eventually be inherited into populations, that is they may represent PICs. Following these PICs in the field could give us insight to the early stages of speciation. They realized that the odds of correctly identifying these characters was slim as most anomalies are either not inheritable or are not inherited successfully into a population. However, the finding of a second PIC in an individual with the Double-Spot Anomaly means it is much more likely to be an inheritable character leading to speciation from the
Butter Hamlet. This could represent the first successful recognition of a PIC leading to a new species.

\section{RESUMEN}

Las fotografías a color del pez vaca bronceado, Hypoplectrus sp., de St. John y St. Thomas, Islas Vírgenes de los Estados Unidos, se presentan a continuación para corregir un error de impresión en una publicación sobre el pez vaca en las últimas Memorias. Estas figuras fueron impresas accidentalmente en blanco y negro, por lo que resultaban inútiles para los diagnósticos. La Anomalía de la Doble Mancha en el pez vaca mantequilla se propuso como un carácter potencialmente hereditario (PIC, por sus siglas en inglés: Potentially Inheritable Character), lo cual podría llevar a la especiación. Se sugirió la identificación y el seguimiento de los PIC en el área con el fin de estudiar la especiación y la evolución. El hecho de haber encontrado un segundo individuo con la Anomalía de la Doble Mancha significa que es más probable que sea un carácter hereditario que lleva a la especiación del pez vaca mantequilla. Esto podría representar el primero reconocimiento exitoso de un PIC que lleva a una nueva especie. 
Palabras clave: características de color, estudio de especialización del área, evolución, Hypoplectrus.

\section{REFERENCES}

Williams, E. H., Jr. and L. Bunkley-Williams. 2005. Rock Beauty crown pattern, grackle scythebill, and Butter Hamlet double spot anomalies, and their possible genetic significance. Proc. Ass. Mar. Lab. Carib 32: 57.
Williams, E.H., Jr. \& L. Bunkley-Williams. 2007. Three anomalies: A scythebill in the Greater Antillean Grackle (blackbird), a crown pattern in the Rock Beauty (angelfish), and a double spot in the Butter Hamlet (grouper), and their possible genetic significance. Rev. Biol. Trop./Int. J. Trop. Biol. Conserv. 54(Suppl. 3): 161-169.

Williams, E.H., Jr., L. Bunkley-Williams, C.S. Rogers \& R. Fenner. 2007. New geographic records of hamlets, Hypoplectrus spp. (Serranidae), in the Caribbean Sea. Rev. Biol. Trop./Int. J. Trop. Biol. Conserv. 54(Suppl 3): 171-173. 